\title{
PENGARUH DOSIS PERENDAMAN EKSTRAK DAUN CENGKEH (Syzygium Aromaticum) TERHADAP DAYA TETAS TELUR IKAN LELE DUMBO (Clarias gariepinus)
}

\section{THE EFFECT OF INFLUENCE OF CLOVE LEAVE EXTRACT (Syzygium Aromaticum) ON HATCHING POWER OF DUMBO CATFISH EGGS (Clarias gariepinus)}

\author{
Baiq Nadya Dwi Yulihastiana*, Nunik Cokrowati, Andre Rachmat Scabra \\ Program Studi Budidaya Perairan, Universitas Mataram \\ Jl. Pendidikan No. 37 Kota Mataram, NTB \\ *Alamat korespondensi : nadyabaiq21@gmail.com
}

\begin{abstract}
Abstrak
Penelitian ini bertujuan untuk mengetahui dosis perendaman ekstrak daun cengkeh terhadap daya tetas telur ikan lele yang optimal dan untuk mengetahui pengaruh perendaman ekstrak daun cengkeh terhadap daya tetas telur ikan lele Penelitian ini dilaksanakan selama 41 hari dari Tanggal 17 November 2020 sampai Tanggal 27 Desember 2020, tempat penelitian dilaksanakan di instalasi Balai Budidaya Batu Kumbung,Lingsar, Lombok Barat. Penelitian ini dilakukan dengan metode eksperimental menggunakan Rancangan Acak Lengkap (RAL) dengan empat perlakuan dan tiga ulangan yaitu perlakuan A: kontrol, B : $50 \mathrm{ppm}$. C : $70 \mathrm{ppm}$ dan D : 90 ppm, E : 11 ppm. Hasil penelitian menunjukkan bahwa tingkat daya tetas ikan lele dumbo (Clarias gariepinus) tertinggi diperoleh pada perlakuan D yaitu mencapai $94,770,17 \%$ dan nilai daya tetas terendah pada perlakuan A yaitu sebesar 33,33 \% Hasil ANOVA menunjukan ada perbedaan signifikan dari Pengaruh pemberian perendaman ekstrak daun cengkeh terhadap daya tetas telur ikan lele dumbo pada setiap perlakuan terdapat aktivitas antifungi, ekstrak daun cengkeh berada pada dosis terbaik dalam mekanisme penghambatan terhadap jamur.
\end{abstract}

Kata Kunci: Ekstrak daun cengkeh, Ikan lele dumbo, Daya tetas telur

\begin{abstract}
This study aims to determine the optimal dose of clove leaf extract immersion on hatchability of catfish eggs and to determine the effect of immersion in clove leaf extract on hatchability of catfish eggs. This research was conducted for 41 days from 17 November 2020 to 27 December 2020, where the research was carried out at the installation of the Kumbung Stone Cultivation Center, Lingsar, West Lombok. This research was conducted with an experimental method using a completely randomized design (CRD) with four treatments and three replications, namely treatment A: control, B: $50 \mathrm{ppm}$. C: $70 \mathrm{ppm}$ and D: $90 \mathrm{ppm}$ E: $11 \mathrm{ppm}$. The results showed that the highest hatchability rate of African catfish (Clarias gariepinus) was obtained in treatment $\mathrm{D}$ which reached $94.770 .17 \%$ and the lowest hatchability value in treatment $\mathrm{A}$ was $33.33 \%$. ANOVA results showed that there was a significant difference in the effect of soaking the extract. Clove leaves against the hatchability of African catfish eggs in each treatment there was anti-fungal activity, clove leaf extract was at the best dose in the inhibition mechanism against fungi.
\end{abstract}

Keywords: Clove leaf extract; African catfish; Hatchability 


\section{PENDAHULUAN}

Ikan lele dumbo (Clarias gariepinus) merupakan salah satu jenis ikan yang potensial untuk dikembangkan sebagai ikan konsumsi. Ikan ini mempunyai beberapa keunggulan diantaranya, relatif tahan terhadap penyakit, tahan terhadap oksigen terlarut yang rendah, memiliki pertumbuhan yang cepat dan sangat responsive terhadap pakan yang diberikan (Suyanto, 2007). Tingginya potensi terhadap ikan ini menyebabkan meningkatnya permintaan sehingga membuat usaha budidaya juga terus dikembangkan.

Menurut susanto (1996), untuk menunjang keberhasilan budidaya ikan, salah satu faktor yang menentukan adalah ketersediaannya benih yang memenuhi syarat baik kualitas, kuantitas, maupun kontinuitasnya. Benih yang tersedia dalam jumlah banyak tetapi kualitasnya rendah haya akan memberatkan petani pembesaran karena hasilnya tidak seimbang dengan kuantitas pakan yang diberikan. Perkembangan usaha ikan lele juga mempunyai beberapa kendala antara lain sering muculnya penyakit. Penyakit yang sering menyerang ikan maupun telur ikan ialah penyakit jamur. Setiawati (2007), menyatakan bahwa ikan lele merupakan ikan yang umum terserang jamur dari jenis saprolegnia sp dari fase telur hingga dewasa. Telur-telur ikan tersebut diserang oleh mikroba jenis jamur yang dapat menyebabkan daya tetas telur menjadi rendah.

Solusi yang dapat dilakukan untuk penyakit pada ikan, antara lain dengan menggunakan bahan alami atau bahan kimia dalam proses budidaya jenis bahan kimia yang umum digunakan sebagai anti jamur adalah methylen blue dan gentian violet selain itu, $\mathrm{NaCl}$ juga diketahui efektif untuk mengobati Saprolegnia sp, dan bahan alami yang umum digunakan berupa tumbuhan, yang sudah dimanfaatkan sebagai pengobatan penyakit $A$. hydrophila antara lain ekstrak bawang putih (Allium sativum) dan ekstrak daun pepaya (Carica papaya).
Adanya kandungan minyak atsiri pada bawang putih mampu menghambat pertumbuhan bakteri A. hydrophila dengan konsentrasi hambat minimum $20 \mathrm{~g} / \mathrm{l}$ (Sholikhah, 2009)

Penggunaan bahan alami lebih direkomedasikan dibandingankan dengan bahan kimia. Pemakaian bahan kimia secara terus menerus dengan dosisi yang berlebihan akan menimbulkan masalah baru berupa meningkatkan resistensi mikroorganisme terhadap bahan tersebut. Masalah lainnya adalah bahayanya yang ditimbulkan terhadap lingkungan, dan manusia yang mengkonsumsinya karena terjadinya akumulasi antibiotik tersebut dalam jaringan terutama tulang ( Prapanza dan Marianto, 2003). Salah satu bahan alami yang dapat digunakan dalam proses pencegahan terjadinya penyakit pada budidaya ikan.

Tanaman Daun Cengkeh (Syzygium aromaticum) merupakan tanaman asli Maluku (Indonesia) yang tergolong ke dalam keluarga tanaman Myrtaceae pada ordo Myrtales (Razafimamonjison, et al., 2015) yang merupakan tanaman herbal telah lama digunakan di negara-negara Timur Tengah. Berkaitan dengan permasalahan tersebut, perlu ada alternatif bahan obat yang lebih aman yang dapat digunakan dalam pengendalian penyakit ikan. Salah satu alternatifnya adalah dengan menggunakan daun Cengkeh yang bersifat anti parasit, anti jamur, anti bakteri menurut (Yuliana, 2014) daun cengkeh mengandung eugenol, saponin, flavonoid dan tanin).Sebagai obatobatan cengkeh dapat digunakan sebagai obat tradisional dalam penyembuhan berbagai macam penyakit. penggunaan tanaman daun cengkeh sebagai bahan penelitian dalam hal peningkatkan reproduksi budidaya ikan telah banyak dilakukan. Dengan memanfaatkan daun cengkeh, diharapkan mampu mencegah terjadinya jamur pada tetas telur ikan lele. Sehingga pentingnya melakukan penelitian ini untuk mengetahui pengaruh perendaman daun cengkeh terhadap daya tetas ikan lele dan dosis perendaman daun cengkeh terbaik terhadap daya tetas telur ikan lele. 


\section{METODOLOGI}

\section{Waktu dan Tempat}

Penelitian ini dilaksanakan selama 41 hari, mulai dari tanggal 17 November sampai dengan 27 Desember 2020 bertempat di instalasi Balai Budidaya Batu Kumbung,Lingsar, Lombok Barat

\section{Alat dan Bahan}

Alat yang digunakan pada penelitian ini adalah $\mathrm{pH}$ meter, Aerasi, Toples plastik, oksigen meter, Kamera, Kertas saring, Termometer, Alat tulis, Timbangan analitik, Blender. Bahan yang digunakan adalah Telur ikan lele dumbo, Air tawar, etanol 96 $\%$, Daun cengkeh

\section{Prosedur Penelitian}

\section{Persiapan Wadah Penelitian}

Persiapan dilakukan dengan menyiapkan wadah toples plastik yang berukuran 2 L sebanyak 15 unit. Setiap wadah pemeliharaan diberikan aerasi menggunakan aerator yang berupa selang dan batu aerasi untuk menyuplai oksigen di dalam wadah pemeliharaan. Wadah dan alat yang tersedia, terlebih dahulu dicuci kemudian dibilas hingga bersih. Wadah dan alat siap untuk digunakan. Selanjutnya wadah ditempatkan sesuai dengan posisi yang telah ditetapkan kemudian diisi dengan air tawar sebanyak 1 L serta dilengkapi dengan aerasi sebanyak satu buah untuk masing-masing toples sebagai suplai oksigen ke dalam air, barulah diberi label sesuai dengan perlakuan.

\section{Pembuatan Ekstrak Daun Cengkeh}

Mengekstrak daun cengkeh dilakukan di Fakultas Matematika dan Ilmu Pengetahuan Alam Laboratorium Kimia, daun cengkeh yang digunakan dicuci bersih dan dikering anginkan selama satu bulan. Setelah kering daun cengkeh dihaluskan dengan blender sampai menjadi serbuk. Serbuk daun cengkeh ditimbang sebanyak 500 gram dan ditambahkan sedikit demi sedikit pelarut etanol $96 \%$ sebanyak 1 liter hingga seluruhnya terendam sambil diaduk, dengan lama perendaman 48 jam. Larutan hasil ekstraksi disaring dengan kertas saring dan hasilnya dimasukkan ke dalam botol tertutup untuk selanjutnya dievaporasi. Ekstrak daun yang diperoleh, dipekatkan dengan menggunakan rotary evaporator pada suhu $58-60^{\circ} \mathrm{C}$ hingga diperoleh larutan yang kental. Ekstak daun cengkeh disimpan dalam freezer sampai digunakan

\section{Penetasan Telur}

Induk lele berasal dari Kolam. Telur berasal dari sepasang induk ikan lele, yang sebelum dipijahkan dipastikan sehat. Pemijahan ikan lele dilakukan secara alami yang dirangsang dengan hormon GnRH (Ovaprim, Syndel Laboratories Ltd.) secara intramuskuler. Dosis yang diberikan adalah $0,4 \mathrm{ml} / \mathrm{kg}$ yang dicampur dengan $0,4 \mathrm{ml}$ $\mathrm{NaCl}$. Setelah memijah, induk ikan dipindah secara hati-hati. Kemudian telur-telur dimasukan ke wadah percobaan dengan volume air 2 liter. wadah yang digunakan berbentuk bulat ukuran 2 liter

\section{Perendaman Telur}

Setelah dilakukan proses pemijahan induk ikan lele dumbo selanjutnya, telurtelur dihitung sebanyak 200 butir dimasingmasing wadah penetasan dan dihitung secara manual untuk dijadikan sampel, kemudian dilakukan perendaman dengan dosis pada penelitian ini terdiri dari beberapa dosis yaitu 0 (kontrol), 50, 70, 90, dan 11 ppm. Di masing-masing dosis dicampurkan $1 \mathrm{~L}$ air untuk perendaman telur ikan lele dumbo, masing-masing waktu perendaman setiap perlakuan selama 35 menit, setelah dilakukan perendaman telur dipindahkan ke wadah penetasan yang berisi air bersih dengan volume $5 \mathrm{~L}$ yang dilengkapi dengan aerasi dan didiamkan selama 24 jam sampai telur menetas dengan sempurna, telur- telur yang telah menetas dan menjadi larva dihitung dan dicatat pada semua perlakuan.

\section{Pemeliharaan Larva}

Pemeliharaan larva dilakukan setelah telur menetas, pada masing-masing toples 
yang berukuran 5 liter dengan mengisi air 4 liter dimasukan 30 larva ikan lele dumbo yang sudah menetas dan diberi satu selang aerasi untuk suplai oksigen. Dalam penelitian ini untuk mengetahui tingkat kelangsungan hidup, larva dimati sampai berumur 30 hari. Dalam masa pemeliharaan larva diberi makan berupa cacing sutra. Larva diamati setiap hari dan data yang diamati adalah berapa banyak larva yang hidup selama masa pemeliharaan 30 hari

\section{Parameter Penelitian}

Daya tetas telur

Perhitungan persentase daya tetas telur ikan lele dumbo dihitung berdasarkan telur yang menetas, dengan menggunakan rumus menurut Estiningsih (1996) adalah sebagai berikut :

$D T(\%)=\frac{T M}{T T} x 100$

Keterangan : DT $=$ Daya tetas telur; $\mathrm{TM}=$ Jumlah telur yang menetas; TT $=$ Jumlah telur yang ditebar.

Intensitas Serangan Jamur

Jamur diamati melalui telur yang terserang Saprolegnia sp, baik telur yang mati (infertil) maupun telur yang terinfeksi. Telur-telur yang terserang jamur akan memperlihatkan tanda-tanda di sekeliling telur terdapat benang-benang yang menyelimuti telur seperti kapas, pengamatan telur yang terserang jamur dilakukan dengan cara visual. Peubah yang diamati pada penelitian ini adalah prevalensi dayatetas (Hatching rate) telur ikan lele sebagai berikut

$\mathrm{P}=\frac{n}{N} x 100 \%$

Keterangan:

$\mathrm{P}=$ Prevalensi; $\mathrm{n}=$ Jumlah sampel yang terinfeksi parasit (ekor); $\mathrm{N}=$ Jumlah sampel yang diamati (ekor)

Kelulushidupan Larva (Survival rate) Untuk menghitung persentase kelulushidupan (survival rate) menggunakan rumus Effendi (1997) yaitu:
$\mathrm{SR}=\frac{N t}{N o} x 100 \%$

Keterangan:

$\mathrm{SR}=$ Tingkat kelulushidup $(\%) ; \mathrm{Nt}=$

Jumlah larva hidup akhir penelitian ; No = Jumlah larva yang hidup awal penelitian

Laju Pertumbuhan Spesifik (LPS)

Laju pertumbuahn spesifik (LPS) dihitung dengan menggunakan rumus dari (Zonneveld et al., 1991) :

$\mathrm{SR}=\frac{\operatorname{LnW} t-\operatorname{LnWo}}{t}+100 \%$

Keterangan:

SGR = laju pertumbuhan harian spesifik $(\% /$ hari $) ; \mathrm{Wt}=$ berat rata \pm rata ikan pada akhir penelitian (g/ekor); $\mathrm{Wo}_{0}=$ berat rata \pm rata ikan pada awal penelitian (g/ekor); $\mathrm{T}=$ waktu (lama pemeliharaan)

\section{Kualitas Air}

Parameter fisika-kimia air yang diamati yaitu suhu, $\mathrm{pH}$ dan oksigen terlarut. Pengukuran suhu dilakukan dengan menggunakan termometer, pengukuran $\mathrm{pH}$ dilakukan dengan menggunakan $\mathrm{pH}$ meter dan pengukuran oksigen terlarut dilakukan dengan menggunakan DO meter. Pengukuran suhu, $\mathrm{pH}$ dan oksigen terlarut dilakukan sebelum perendaman telur dengan ekstrak daun cengkeh.

Tabel 1. Parameter Kualitas air

\begin{tabular}{llcl}
\hline No & Parameter & Satuan & Alat Uji \\
\hline 1 & Suhu & ${ }^{\circ} \mathrm{C}$ & Termomrter \\
2 & DO & $\mathrm{mg} / \mathrm{L}$ & Oksigen \\
& & & $\begin{array}{l}\text { Meter } \\
\text { pH Meter }\end{array}$ \\
\hline
\end{tabular}

\section{Analisis Data}

Data dari hasil penelitian akan dianalisis dengan menggunakan Analisis Varian (ANOVA) ,untuk mengetahui pengaruh dari perlakuan dalam penelitian. Jika data menunjukkan pengaruh nyata, 
maka dilakukan analisis lanjut dengan uji ducan.

\section{HASIL DAN PEMBAHASAN}

\section{Daya Tetas Telur}

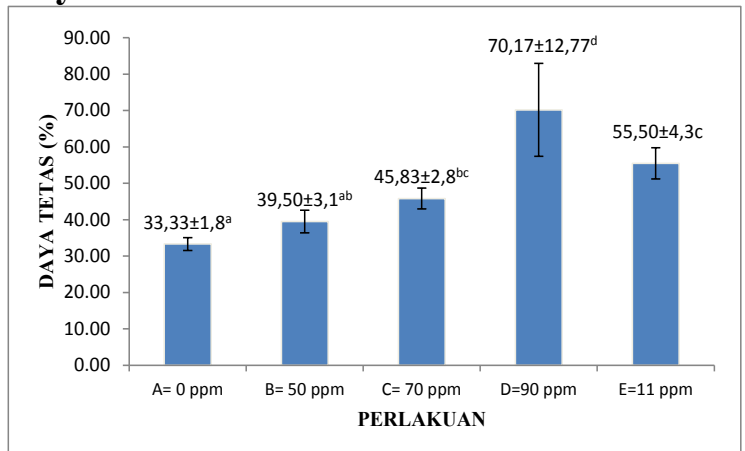

Gambar 1. Daya Tetas Telur

Berdasarkan data hasil penelitian yang ditunjukkan pada Tabel 1, bahwa daya tetas telur ikan lele semakin meningkat dari dosis 0 ppm hingga mencapai puncaknya pada dosis $90 \mathrm{ppm}$. Hal ini menunjukan bahwa perlakuan perendaman ekstrak Daun Cengkeh berpengaruhterhadap daya tetas telur ikan lele dibuktikan dengan nilai daya tetas telur cenderung meningkat dibandingkan dengan tanpa perlakuan perendaman $(0 \mathrm{ppm})$. Melalui uji analisis ragam menunjukkan bahwa perlakuan perendaman ekstrak daun cengkeh berpengaruh sangat nyata terhadap daya tetas telur ikan lele. Hal ini membuktikan bahwa senyawa yang terkandung dalam ekstrak daun cengkeh bekerja aktif sebagai zat anti jamur. Senyawa yang terkandung dalam daun cengkeh yang berfungsi sebagai zat anti jamur meliputi senyawa metabolit sekunder berupa, flavonoid, saponin dan tannin. sesuai dengan pernyataan ( Ristiansyah et al 2018) adanya antioksidan alami tumbuhan adalah senyawa fenolik dapat ditemukan dalam rempah seperti daun cengkeh mengandung saponin, flavonoid, tanin dan minyak astiri.

\section{Intensitas Serangan Jamur}

Hasil analisa menunjukan intensitas serangan jamur, menunjukkan bahwa terdapat perbedaan nyata pada berbagai perlakuan ekstrak daun cengkeh $(\mathrm{p}<0,05)$ (Gambar 2).

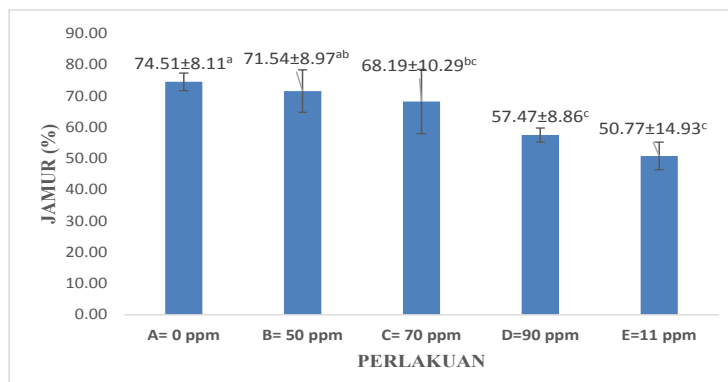

Gambar 2. Intensitas Serangan Jamur.

Persentase jamur dilihat melalui telur ikan yang tidak menetas dengan ditumbuhi jamur. Pengamatan dilakukan dengan kasat mata dan dengan bantuan mikroskop. Berdasarkan hasil pengamatan yang telah dilakukan didapatkan hasil persentase telur ikan lele dumbo yang terserang Saprolegnia sp. Tertinggi pada perlakuan $0 \mathrm{ppm}$ yaitu $74,51 \%$ dan presentase terrendah pada perlakuan 11 ppm yaitu 50,77\%. Berdasarkan hasil di atas bahwa perendaman telur ikan lele dalam ekstrak daun Cengkeh memberikan rerata persentase serangan jamur Saprolegnia sp. terendah yaitu pada dosis $11 \mathrm{ppm}$ sebesar $0 \%$, selanjutnya berturut-turut diikuti oleh dosis $90 \mathrm{ppm}$ yaitu sebesar 57,47 \%, dosis 7 ppm sebesar $68,19 \%$, dosis 50 ppm sebesar $71,54 \%$, dan terakhir serangan jamur Saprolegnia sp. tertinggi pada perlakuan dosis 0 ppm yaitu sebesar 74,51 \%. Hal ini menyebabkan pertumbuhan jamur yang tak terkendali sehingga jamur terus menyerang telur yang sehat dan mengakibatkan telur yang tadinya sehat menjadi mati dan tidak menetas. Telur yang terserang jamur akan memperlihatkan tanda-tanda disekeliling telur terdapat benang-benang halus seperti kapas dan berwarna putih. Ciri jamur tampak seperti yang dinyatakan oleh (Siregar \& Adelina, 2012)

\section{Kelulushidupan Larva (Survival rate)}

Hasil analisa kelulushidupan larva selama 30 hari masa pemeliharaan menunjukkan adanya perbedaan nilai kelulushidupan larva. 


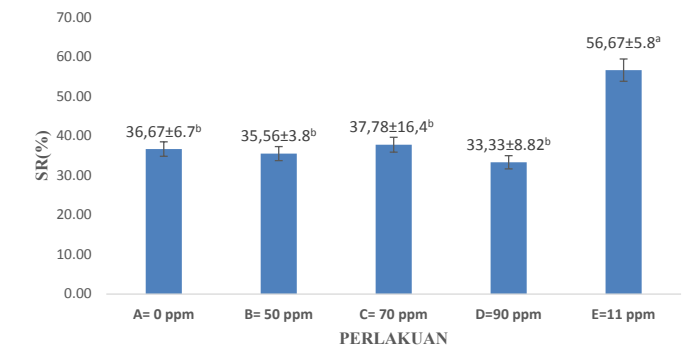

Gambar 3. Kelasungan Hidup (SR).

Tingkat kelangsungan hidup ikan lele dumbo selama masa pemeliharaan berkisar antara 33,33\% - 56,57\%. Selama pemeliharaan terjadi kematian beberapa ekor ikan pada seteiap wadah. Hal ini lebih banyak terjadi pada hari ke 7 hingga hari ke 14 pemeliharaan. Diduga karena stres akibat belum dapat beradaptasi dengan wadah pemeliharaan yang baru yaitu wadah toples. Kematian juga disebabkan oleh ukuran dan umur ikan yang masih rentan untuk dapat bertahan hidup dengan baik, pengaruh respon dari luar misalnya saat penyiponan dan juga kelangsungan hidup sangat berhubungan dengan kualitas air, dimana jika kualitas air baik maka nilai SR akan baik dan sebaliknya jika kualitas air buruk maka nilai SR dapat menurun. Hal ini sejalan dengan pendapat Gusman dan Muhammad (2014) dalam (Mustofa et al., 2018)yang menyatakan bahwa tingkat kelangsungan hidup pada ikan banyak dipengaruhi oleh faktor lingkungan, misalnya penanganan dan kualitas air. Penanganan yang salah dapat menyebabkan ikan stres, sehingga kondisi kesehatan ikan menurun dan dapat menyebabkan kematian. Pada penelitian ini kualitas air selalu dijaga dengan melakukan penyiponan rutin untuk mengeluarkan feses dan sisa pakan yang tidak termakan yang dapat merusak kualitas air.

\section{Laju Pertumbuhan Spesifik (SGR)}

Hasil analisa laju pertumbuhan spesifik larva Ikan lele selama 30 hari pemeliharaan menunjukkan bahwa perlakuan ekstrak daun cengkeh tidak memberikan hasil yang tidak berbeda nyata terhadap kelangsungan hidup Ikan lele ( $\mathrm{p}>$ 0,05) (Tabel 4).

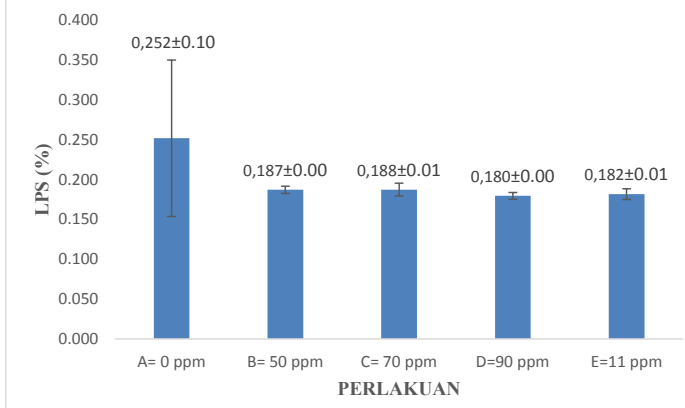

Gambar 4. Laju Pertumbuhan Spesifik (SGR).

Laju pertumbuhan Spesifik (SGR) tertinggi terdapat pada perlakuan A yaitu berkisar antara dengan nilai rata-rata $0,252 \%$ Peningkatan berat tubuh ikan lele dumbo selama penelitian menunjukkan adanya pertumbuhan. Pertumbuhan sebagai pertambahan dalam volume dan berat dalam waktu tertentu. Pertumbuhan ikan lele dumdo disebabkan oleh beberapa faktor, pertumbuhan Pada pelakuan A memiliki pertumbuhan spesifik yang cukup tinggi, Adapun faktor yang mempengaruhi laju pertumbuhan pada saat pertama jumlah berat ikan berbeda-beda dan ukuran ikan pada padat tebar ini tidak seragam yang menyebabkan laju pertumbuhan spesifik berdeda-beda. Hal ini sesuai dengan pernyataan Hickling (1971) dalam Indri et.al 2018 menambahkan bahwa laju pertumbuhan harian ikan dipengaruhi oleh makanan, suhu dan umur ikan. Laju pertumbuhan juga dipengaruhi oleh kompetisi mendapatkan makanan seperti jumlah nafsu makan ikan yang berbeda-beda, Sesuai dengan pernyataan Siregar dan (Fitria, 2012) pertumbuhan dapat dipengaruhi oleh faktor biotik dan abiotik. Faktor biotik terdiri dari umur dan kemampuan ikan dalam mencukupi kebutuhan pakan, faktor abiotik antara lain ketersediaan makanan dan kualitas media hidup. Laju pertumbuhan Spesifik (LPS) juga dipengaruhi oleh pertambahan bobot tubuh setiap perlakuan lebih dari jumlah pakan yang diberikan, hal ini bisa terjadi karena adanya kanibalsime diantara sesama ikan yang dipelihara, sehingga bobot tubuh ikan tidak hanya berasal dari jumlah pakan yang diberikan 
saja tetapi juga berasal dari bobot tubuh ikan yang dikanibal. Dimana pemberian pakan alami selama pemeliharaan berupa cacing sutra, cacing sutra merupakan pakan alami yang sesuai untuk benih ikan karena pakan alami mudah dicerna dan mengandung gizi yang tinggi. Kandungan protein yang terdapat pada cacing sutra (Tubifex) yaitu sebesar $57 \%$. pakan yang mempunyai nutrisi yang baik sangat berperan dalam mempertahankan kelangsungan hidup. Hal tersebut juga mempengaruhi pertumbuhan berat dari larva ikan lele dikarnakan semakin banyak protein yang mengandung dalam pakan ikan dapat mempercepat laju pertumbuhan ikan tersebut.

\section{Kualitas Air}

Tabel. 2 Hasil Kualitas air pada perendaman telur ikan lele

\begin{tabular}{ccccccc}
\hline \multirow{2}{*}{ Parameter } & \multicolumn{5}{c}{ PERLAKUAN } & \multirow{2}{*}{ REFRENSI } \\
\cline { 2 - 6 } & $0 \mathrm{ppm}$ & $50 \mathrm{ppm}$ & $70 \mathrm{ppm}$ & $90 \mathrm{ppm}$ & $11 \mathrm{ppm}$ & $6-8,5$ Hermawan et al., \\
\hline $\mathrm{pH}$ & 6,5 & 7.4 & 7,8 & 7.6 & 7.4 & $(2012)$ \\
\hline Suhu & 25.6 & 29.98 & 28.4 & 25.4 & 27.2 & $26-31^{\circ} \mathrm{C}$ Mahary 2017) \\
\hline DO & 7.3 & 7.4 & 7,0 & 6.0 & 7.18 & $4-7 \mathrm{mg} / 1$ (Kesuma, 2019) \\
\hline
\end{tabular}

Tabel. 3 Hasil Kualitas air pada pemeliharaan larva

\begin{tabular}{ccccccc}
\hline \multirow{2}{*}{ Parameter } & $0 \mathrm{ppm}$ & $50 \mathrm{ppm}$ & $70 \mathrm{ppm}$ & $90 \mathrm{ppm}$ & $11 \mathrm{ppm}$ & \multirow{2}{*}{ REFRENSI } \\
\cline { 2 - 6 } $\mathrm{pH}$ & $6,8-7,6$ & $6.6-7.4$ & $6.6-7.4$ & $6.6-7.6$ & $6.6-7.4$ & $\begin{array}{c}6-8,5 \text { Hermawan } \\
\text { et al., (2012) }\end{array}$ \\
\hline Suhu & $25.6-27,2$ & $26.9-26.98$ & $26.6-27.4$ & $25.2-26.6$ & $26.4-27.2$ & $\begin{array}{c}26-31^{\circ} \mathrm{C} \text { Mahary } \\
2017)\end{array}$ \\
\hline DO & $7.12-7.68$ & $6.74-7.20$ & $7-7.14$ & $6.88-7.14$ & $6.78-7.18$ & $\begin{array}{c}4-7 \mathrm{mg} / 1 \\
(\text { Kesuma, 2019) }\end{array}$ \\
\hline
\end{tabular}

\section{Hasil analisa kandungan ekstrak daun cengkeh}

Berdasarkan hasil uji analisa kandungan dengan uji fitokimia daun cengkeh sebagai berikut:

Tabel. 4 Analisa kandungan daun cengkeh

\begin{tabular}{llc}
\hline No & \multicolumn{1}{c}{ Test/Uji } & $\begin{array}{c}\text { Sampel Daun } \\
\text { Cengkeh }\end{array}$ \\
\hline 1. & Flavonoid & + \\
2. & Alkaloid & + \\
& (Dragendrop, & \\
& Mayer, Wagner) & \\
3. & Steroid/Terpenoid & + \\
4. & Saponin & + \\
5. & Tanin & + \\
6. & Fenolik & + \\
\hline
\end{tabular}

Keterangan: $(+)$ Terjadi reaksi/perubahan warna sesuai uji, (-) Tidak terjadi reaksi/perubahan warna

\section{Kualitas Air}

Kualitas air mempunyai peranan penting sebagai pendukung kehidupan dan pertumbuhan larva ikan lele sangkuriang (Clarias gariepinus). Hasil pengamatan terhadap parameter kualitas air yang meliputi suhu, $\mathrm{pH}, \mathrm{DO}$, pada semua perlakuan disajikan pada Tabel 1. Kisaran suhu selama penelitian pada setiap perlakuan adalah $26.9-27.2^{\circ} \mathrm{C}$, dimana suhu tersebut masih dalam kisaran normal. Pada Tabel 8 menunjukkan kisaran suhu pada $\mathrm{A}$ (0 ppm) dengan $25.6-27.7^{\circ} \mathrm{C}, \mathrm{B}(50 \mathrm{ppm})$ dengan $26.9-26.98^{\circ} \mathrm{C}$ dan pada $\mathrm{C}(70 \mathrm{ppm})$ dengan $26.6-27.4^{\circ} \mathrm{C} \mathrm{D}(90 \mathrm{ppm})$ dengan 26.6-27. $4^{\circ} \mathrm{C}$ E (11 ppm) dengan 26.4 $27.2^{\circ} \mathrm{C}$ Hasil ini telah sesuai dengan suhu yang optimal bagi pertumbuhan larva ikan lele, dimana penelitian dilakukan pada ruangan tertutup dan dalam lingkungan yang relatif homogen. Menurut (Mahary, 
2017) menyatakan bahwa suhu yang ideal dalam budidaya ikan lele berkisar antara 26$31{ }^{\circ} \mathrm{C}$. Suhu air yang sesuai akan meningkatkan aktivitas makan ikan, sehingga pertumbuhan larva ikan lele akan semakin baik. Perbedaan perlakuan frekuensi pemberian pakan selama penelitian tidak menyebabkan perubahan suhu air yang besar.

Kemampuan air untuk mengikat atau melepaskan sejumlah ion hydrogen akan menunjukkan apakah larutan tersebut bersifat asam atau basa. Derajat keasaman $(\mathrm{pH})$ pada setiap perlakuan selama penelitian berkisar antara 6.8-7.6, hasil ini masih dalam keadaan normal untuk pertumbuhan dan kelangsungan hidup larva ikan lele. Menurut (Hermawan et al., 2012) menyatakan bahwa nilai $\mathrm{pH}$ yang optimum untuk buidaya ikan lele berkisar antara 6 8,5 . Keadaan $\mathrm{pH}$ yang dapat mengganggu kehidupan ikan adalah $\mathrm{pH}$ yang teralu rendah (sangat asam) dan $\mathrm{pH}$ yang terlalu tinggi (sangat basa)

Oksigen merupakan satu parameter yang sangat penting bagi seluruh organisme dalam kehidupannya. Kandungan oksigen yang tidak mencukupi kebutuhan ikan dapat menyebabkan penurunan daya hidup ikan yang mencakup seluruh aktifitas ikan, seperti berenang, pertumbuhan dan reproduksi. Pada Tabel 3 dapat dilihat bahwa kandungan oksigen terlarut (DO) pada setiap perlakuan selama penelitian yaitu berkisar antara 6.88-7.68 mg/l. Kisaran nilai oksigen yang tinggi selama masa pemeliharaan ini disebabkan karna kontrol kualitas air yang baik seperti aerasi terhadap air dan pengangkatan sisa pakan di dasar akuarium yang tidak dimakan oleh larva ikan dari media pemeliharan serta melakukan penyiponan setiap minggunya. Kadar oksigen terlarut yang sesuai untuk budidaya ikan lele menurut Effendi (2003) dalam (Suwarsito et al., 2020) adalah 5 ppm dan lebih baik jika 7 ppm. Oksigen teralarut sangat diperlukan untuk respirasi dan metabolisme serta berpengaruh terhadap kelangsungan hidup ikan

\section{KESIMPULAN DAN SARAN}

\section{Kesimpulan}

Berdasarkan hasil penelitian ini dapat disimpulkan sebagai berikut:

1. Pemberian ekstrak daun cengkeh berpengaruh nyata terhadap daya tetas telur ikan lele dumbo, kandungan yang dimemiliki daun cengkeh berupa senyawa anti jamur berupa flavonoid, tanin, saponin,alkaloid, steroid, dan fenolik

2. Pemberian ekstrak daun cengkeh berpengaruh nyata $(\mathrm{P}<0,05)$ terhadap parameter daya tetas telur ikan lele dumbo dengan konsentrasi optimum diperoleh pada konsentrasi 9 ppm. Daya tetas tertinggi pada penelitian ini diperoleh sebesar $70,17 \%$.

\section{Saran}

Ekstrak daun cengkeh dapat digunakan sebagai anti jamur yang ramah lingkungan, sehingga mudah diaplikasikan oleh pembudidaya

\section{DAFTAR PUSTAKA}

Fitria, A. S. (2012). Analisis Kelulushidupan dan Pertumbuhan Benih Ikan Nila Larasati (Oreochromis niloticus) F5 D30-D70 pada Berbagai Salinitas. Journal of Aquaculture Management and Technology, 1(1), 18-34.

Hermawan, A., -, I., \& Subhan, U. (2012). Pengaruh Padat Tebar Terhadap Kelangsungan Hidup Pertumbuhan Lele Dumbo (Clarias gariepinus burch.) Di Kolam Kali Menir Indramayu. Jurnal Perikanan Dan Kelautan Unpad, 3(3), 85-93.

Mahary, A. (2017). Pemanfaatan tepung cangkang kerang darah (Anadara granosa) sebagai sumber kalsium pada pakan ikan lele (Clarias batrachus sp). Acta Aquatica: Aquatic Sciences Journal, $\quad 4(2), \quad 63$. https://doi.org/10.29103/aa.v4i2.304

Mustofa, A., Hastuti, S., \& Rachmawati, D. (2018). Pengaruh Periode Pemuasaan 
Terhadap Efisiensi Pemanfaatan Pakan, Pertumbuhan Dan Kelulushidupan Ikan Mas (Cyprinus carpio). Pena Akuatika : Jurnal Ilmiah Perikanan Dan Kelautan, 17(2), 1827.

https://doi.org/10.31941/penaakuatika .v17i2.705

Prapanza, E. dan Marianto, L.M. 2003. Khasiatdan Manfaat Sambiloto: Raja Pahit Penakluk Aneka Penyakit. Agro Media Pustaka. Hal: 1- 10.jannah, n. 2004. Diversifikasi Penggunaan Cengkeh, perspektif, Vol. 3(2), 61-70. http://jbdp.unbari.ac.id/index.php/AK UAKULTUR/article/download/59/42

Siregar, Y. I., \& Adelina, A. (2012). Pengaruh Vitamin $\mathrm{C}$ terhadap Peningkatan Hemoglobin $(\mathrm{Hb})$ Darah dan Kelulushidupan Benih Ikan Kerapu Bebek (Cromileptes altivelis). Jurnal Natur Indonesia, 12(1), 75. https://doi.org/10.31258/jnat.12.1.7581

Subagja, J., \& D. Radona. (2017).
Produktivitas Pasca larva Ikan Ikan Semah Tor douronensis (Valenciennes, 1842) pada Lingkungan Ex Situ dengan Padat Tebar Berbeda. Jurnal Riset Akuakultur, 12 (1), 41- 48. http://dx.doi.org/10.15578/jra.12.1.20 $\underline{17.41-48}$

Suwarsito, S., Kamila, A. H. Z., \& Purbomartono, C. (2020). Kajian Kesesuaian Kualitas Airtanah Untuk Budidaya Ikan Lele (Clarias gariepinus) Di Desa Karangsari Kecamatan Kembaran Kabupaten Banyumas. Sainteks, 17(1), 1. https://doi.org/10.30595/sainteks.v17i 1.8414

Suyanto, S. R. 2006. Budidaya Ikan Lele. Jakarta: Penebar Swadaya

Yuliana, A. (2014). Jurnal Kesehatan Bakti Tunas Husada Volume 11 No.1 Februari 2014. 11(1), 46-58. 